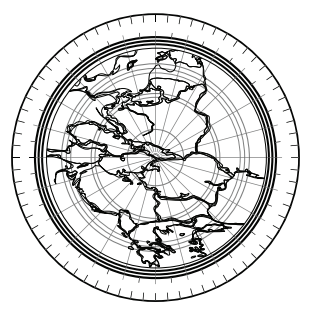

\title{
The Cult of the Martyr: The Symbol of Stanisław Wacławski and Rituals of Violence in the Warsaw Student Milieu of the 1930s
}

DOI: https://doi.org/10.11649/sn.2545

\author{
Izabela Mrzygłód \\ Faculty of History, University of Warsaw \\ https://orcid.org/0000-0002-7312-9361 \\ e-mail: iza.mrzyglod@gmail.com
}

\begin{abstract}
Violence was a key element of the interwar radical habitus and was particularly affirmed in far-right movements, which found fertile ground for their ideas among students. However, the influence of the systems of ideas advocated by ideologues on student masses seems limited and indirect. Student support for antisemitism and extremism cannot be explained only by cultural conditions, ideology or political engineering. What is needed here are intermediate stages, linking radical ideology with the actions of social actors. I argue that the intermediary function was performed by the symbol of Stanisław Wacławski, a student and member of the Camp of Great Poland (Obóz Wielkiej Polski) who was killed during the antisemitic riots in Vilnius in 1931. The figure of Wacławski was a key element of antisemitic discourse in far-right press and was used by academic societies to construct the annual ritual of violence in the 1930s. I employ the micro-sociological approach and draw on Randall Collins' theory of "interaction
\end{abstract}

Work on the article was enabled by a grant from the National Science Centre, Poland, contract no. 2017/24/T/HS3/00186. No competing interests have been declared.

Publisher: Institute of Slavic Studies, Polish Academy of Sciences.

This is an Open Access article distributed under the terms of the Creative Commons Attribution 3.0 PL License (creativecommons.org/licenses/by/3.0/pl/), which permits redistribution, commercial and non-commercial, provided that the article is properly cited. (c) The Author 2021. 
ritual chains" to show that the factors behind the mobilization of ordinary students for collective violence and a chauvinistic agenda included also emotions and personal relations, and not only political identification and advertising.

Keywords: far-right; collective violence; antisemitism; interaction ritual chains; Stanisław Wacławski; students; interwar Poland

\section{Introduction $^{1}$}

In 1933 Elchonon Lewin, a graduate of Warsaw University and a leader of a Jewish union of mutual aid societies, wrote: "Autumn is coming, a gloomy Polish November, drab and frosty - and at the same time [...] the usual Jewish season [...] the boycott of booksellers in Św[ięto]Krzyska Street was irrevocably followed by excesses of right-wing attackers armed with clubs (pałkarskie ekcesy)" (Niwel, 1933, p. 1). Two years later, he seemed to develop the same idea:

These incidents did not give the impression of elemental and spontaneous excesses, but on the contrary... they were clearly inspired and carefully prepared in advance by some quasi-ideological forces. [...] The Jews were to fall [...] victim to the militant narendecki hooliganism. ${ }^{2}$ Everything played out according to a boring and banal ritual which should have already disgusted the more intelligent arrangers of the virulent anti-Jewish campaign. (E. L., 1935, p. 3)

The student columnists writing in Jewish mutual aid associations' journals drew attention to the repetitiveness, planning, political inspiration and the well-known scenario of violence, and predicted with a certain fatalism how the next academic year would begin. Historians studying political life at Polish universities in the 1930s have investigated these observations, diagnosing massive participation of first-year students in acts of aggression as well (Garlicki, 2008; Majewski, 2016, p. 281; Natkowska, 1999). Far-right organizations treated violence as a tool of control over university area and a way of mobilizing their members and attracting new ones. Researchers, therefore, have interpreted it as a kind of political engineering employed by far-right activists (Lipski, 2015, p. 87; Natkowska, 1999; Rudnicki, 2018, p. 183). In this perspective, the key to understanding the attitudes of student masses and the driving force behind their actions is chauvinistic and antisemitic

1 I would like to thank Łukasz Bertram, Karolina Ćwiek-Rogalska, Natalia Judzińska and Zachary Mazur for their insightful comments on earlier versions of this article. I am also very grateful to the two anonymous reviewers for their valuable suggestions.

2 Narendencki is a neologism created to describe the far-right character of university violence. It is a combination of the abbreviation Nara, used with reference to the national-radical movement, and the term Endecja, used to describe the camp of National Democracy. 
ideology of the far-right organizations. The dislike of Polish students for their Jewish peers complements this picture. As researchers point out, traditional anti-Jewish convictions and antisemitism, fostered both at home and at school, constituted fertile soil for the agitation of far-right (Garlicki, 2008; Majewski, 2016, p. 281). However, did antisemitic attitudes necessarily result in involvement in acts of aggression? Why were students prone to violence? What made chauvinist agitation at the universities successful? These questions are missing in the research conducted so far.

Meanwhile, antisemitic acts of aggression must be unwrapped since there are still many unknowns. Motivation stemming from the presented worldview or political ideology is, of course, a convenient explanation in research on collective violence. Nevertheless, as Lech Nijakowski writes in his book on genocide: "the influence of the systems of ideas advocated by the ideologues of various movements [...] on the masses seems limited and indirect. One can study the intellectual lineage of genocidal ideology, but this does not explain its social agency" (Nijakowski, 2013, p. 220). The same is true of collective violence understood more broadly, beyond the extreme context of genocide. Pointing at cultural conditions, ideology or frustration resulting from economic crisis does not solely explain people's willingness to employ violence in social life. Similarly, this cannot be fully clarified by the deliberate efforts of activists who persuade a given group to act aggressively. What is needed here are the intermediate stages, linking radical ideology and nationalist discourse with the actions of social actors. This requires the examination of channels through which political socialization and mobilization for violence take place.

This article does not deny the significance of political and cultural antisemitism in collective violence at universities, but it highlights discourses and emotions associated with a symbol as intermediary mechanisms. Therefore, the aim of this study is to analyze the figure of Stanisław Wacławski (1910-1931), a student from Vilnius who died during the anti-Jewish riots in November 1931, and the ritual created by far-right groups around him. His death was quickly elevated to the status of a symbol, and his figure became an important point of reference among the far-right student youth in all academic centers of interwar Poland. I focus on Warsaw students, showing the course of successive anniversaries of Wacławski's death, as well as feelings and interactions within the group that enabled the ideology to be turned into action. The choice of the Warsaw student milieu and the local university was due to their vital role on the academic map of the Polish Second Republic and the fact that it was Warsaw University that became the nest of the nationwide national-radical movement. In the interwar period, institutions of higher education in Poland, like in other countries of Central and Eastern Europe, became a hotbed of extremism and political violence (Rossoliński-Liebe \& Starek, 2016). My study, then, explores this at the micro level, but its conclusions are important for understanding radicalization mechanisms in Polish public life in the 1930s.

This article focuses on both ordinary participants of annual celebrations and the activities of far-right organizations using the ideology of chauvinism, which played first fiddle 
in mutual aid student societies. I examine activities of such organizations as the All-Polish Youth (Młodzież Wszechpolska), the Camp of Great Poland (Obóz Wielkiej Polski, OWP), the National Radical Camp (Obóz Narodowo-Radykalny, ONR), the National-Radical Movement (Ruch Narodowo-Radykalny, RNR), which grew out of the latter, and the Academic Section of the National Party (Sekcja Akademicka Stronnictwa Narodowego, SA SN). Wacławski became an icon for all of them. The circumstances of his death were described by historian Aleksander Srebrakowski, who reproduced many elements of the interwar far-right narrative, and recently by historian Natalia Aleksiun, who has thoroughly and exhaustively analyzed them and evidenced the political inspiration of the Vilnius riots, also paying attention to the beginnings of the construction of the Wacławski myth (Aleksiun, 2019; Srebrakowski, 2004). The existing literature concerning the figure of Wacławski argues its prominence in the antisemitic discourse and political propaganda of the farright, and captures the crucial role of the anniversary of Wactawski's death in antisemitic protests and violent campaigns at universities (Bukowska-Marczak, 2019, pp. 153-155; Graboń, 2008, pp.167-177; Majewski, 2016, p. 283; Michlic, 2006, pp. 126-128; Natkowska, 1999; Żyndul, 1994, pp. 11-16). However, none of these works shows the step by step process of constructing the symbol of Wacławski in the academic environment, nor reveals the reasons for its powerful effect on the hearts and minds of the youth. Also, they have not explored the sociological and psychological mechanisms behind collective violence repeated around the anniversary of Wacławski's death.

To fill this gap, I employ the micro-sociological approach and draw on Randall Collins' theory of "interaction ritual chains" to show that the factors behind the mobilization of students include also emotions and rituals, and not only political identification and advertising. The familiar-sounding word "ritual", which connotes an established form for a ceremony or a social custom, in this case is the key to examining the interplay between the participants in student demonstrations and riots. In this approach, a ritual is a mechanism of mutually focused emotions and attention, creating a temporarily shared reality which is the basis for the emergence of solidarity and the construction of symbols of group belonging (Collins, 2014). This mechanism can then lead to a shift in attitudes and emotions of those involved. Collins, inspired by Émile Durkheim and Erving Goffman, assumes that the situation is the starting point for understanding interactions and emotions (Collins, 2014, pp. 3-6), in other words, that "incidents shape their incumbents" (Collins, 2014, p. 5).

Thus, I analyze discourses and practices that commemorated Wacławski as a process of constructing emotions and meanings around it, and I read repeated riots and violent attacks at Warsaw institutions of higher education as interaction ritual chains. Such an approach makes it possible to carry out a fruitful analysis of the processes of political action of actors who, at least initially, were not necessarily ideologically motivated, but were able to engage in a political movement as well as in various acts of violence. It makes it possible to show how collective violence could shape their participants, influence individual experiences, and forge short- and long-term political attitudes. With the scarcity of sources on the emotions 
and personal motives of students involved in the riots, such as ego-documents or witness statements in disciplinary proceedings, when only press narratives are at the historian's disposal, Collins' analytical model enables me to get closer to the experience of the student community and understand the interactions between its members. It also gives a chance to see through the smoke of political ideology and capture the feelings of average and accidental participants of demonstrations and collective violence.

\section{The Emergence of Interaction}

The focal point of the cult of Stanisław Wacławski was the anniversary of his death, when his figure and the interpretation of his death consistent with the antisemitic political program of the far-right academic and political organizations were recalled. Let us return to the events of 10 November 1931, then. On Tuesday morning, during the anti-Jewish riots at the Stefan Batory University in Vilnius (hereafter SBU), Stanisław Wacławski was hit by a stone on the head and, as a result, he died. He was a first-year law student and a member of the OWP, coming from a peasant family from Sieniawa in the Lviv province. Nationalist youth demonstrations had started in Vilnius a day earlier, but political and ethnic tensions had been building up for a few days before the tragic event. ${ }^{3}$ This fraught atmosphere was created by the reports of antisemitic riots in other cities and rumors of far-right demonstrations being prepared in Vilnius. As at other universities, the so-called "Cadaver Affair", i.e. the dispute over the question whether to allow Jewish medical students to practice anatomy and autopsy on the bodies of Christians, especially Christian newborns, became a pretext for aggression. ${ }^{4}$ Violence at the Institute of Anatomy quickly escalated and spilled over to other faculties, and then spread to the streets as well. There were clashes between nationalist students and Jewish students defending themselves, and Poles who opposed the methods used by the OWP. Some Polish and Jewish residents of Vilnius also joined the riots.

Wacławski was wounded during the clashes near the university campus and taken by horse-drawn carriage to hospital, where he died shortly afterwards. According to the nationalist press, the carriage was attacked by a Jewish militia, pelted with stones and shot at, and Wacławski was injured on the head, this time fatally ("Krwawe zajścia w Wilnie", 1931). However, this version was not confirmed during the investigation conducted

\footnotetext{
3 Anti-Jewish demonstrations and violence at universities followed the riots at the Jagiellonian University on 23 October 1931. Also in Warsaw the whole beginning of November was marked by student terror (Natkowska, 1999, pp. 8-10).

4 Demands by Polish medical students for Jewish communities to provide cadavers for dissecting rooms so that Jewish students would only dissect the bodies of dead Jews appeared at universities in 1921. Despite the agreements made between university authorities and Jewish communities, the issue recurred regularly throughout the interwar period, becoming a pretext for antisemitic violence (Aleksiun, 2011, 2012).
} 
by the rector of SBU. ${ }^{5}$ The death of the student, although it had an impact on stopping violence in Vilnius, occasioned anti-Jewish rallies and resolutions. Moreover, his twoday funeral (12-13 November 1931) turned into a far-right demonstration. And on his tombstone at the Antakalnis Cemetery in Vilnius the following inscription was engraved: "STANISŁAW WACŁAWSKI / A STUDENT OF SBU / A MEMBER OF THE OWP / FELL IN THE FIGHT FOR GREAT POLAND / STONED BY THE JEWS / 10 November 1931". As such, it contained an unambiguous interpretation of the tragic events, pointing to the guilty party, and referring to the concept of Great Poland, an imperial state of ethnic Poles. At the same time, it also associated the death of the student with the martyrdom of the ancient Christians, e.g. the stoning of St. Stephen, the first martyr. Later on, Wacławski's grave became the site of nationalist celebrations (e.g. W dniu 10-go listopada 1935 roku mija czwarta rocznica, 1935; W dniu 10 listopada 1937 r. mija 6 lat, 1937).

The first year after the events in Vilnius was of key importance for the creation and maintenance of the interaction ritual around the figure of Wacławski as a victim and "fighter for the Polishness of universities" (Lachowicz, 1939). At that time, the far-right student groups gave meaning to Wacławski's death, and effectively preserved the emotional energy of the first days of mourning. The news about the events at Vilnius University spread at the University of Warsaw when the emotions related to the recent "Cadaver Affair", which had caused riots also in the capital, had not yet subsided. "Unheard of, tragic, terrifying news from Vilnius", as one of the student leaders reported (Kurcyusz, 1932, p. 21) - it was a strong emotional stimulus, and the academic community was deeply disturbed by the information about the death of their fellow student. ${ }^{6}$ On 10 November, just a few hours after Wacławski's death, a gathering assembled in the dormitory complex at Grójecka Street, and - as reported in the pro-government daily Gazeta Polska [Polish Gazette]" - "a series of inflammatory speeches was delivered". Thus, activists of extreme right-wing organizations became active almost immediately. Groups of students tried to hold demonstrations in the streets of the city, but the police managed to keep order ("Echa hec", 1932).

The fact of the student's death shocked not only the nationalist youth but also a much wider circle of the student milieu. According to press reports, the memorial service at St. Anne's Academic Church at Krakowskie Przedmieście in Warsaw gathered about 7,000 participants ("Spokojny przebieg", 1931). The Vilnius events were also widely commented on in the academic press of all ideological shades, although the socialist and democratic youth blamed

\footnotetext{
5 The carriage was in fact pelted with stones by the crowd during the riots. Whether Wacławski was wounded again remains a matter of dispute (Aleksiun, 2019, p. 342; Srebrakowski, 2004, p. 594).

6 The Warsaw press published extensive comments on the riots in Vilnius (Zackiewicz, 2011).

7 Gazeta Polska was the main, semi-official daily of the ruling Sanacja camp, issued in 1929-1939. In 1926, Poland's military hero Józef Piłsudski staged a coup d'état that led to the rise of Sanacja, meaning variously "cleansing" or "healing". The term was initially used with reference to the ruling group, evoking the notion of mending political and social relations in Poland. Although the core of the Sanacja camp was composed of military officers, progressive intelligentsia and left-leaning activists, the regime took an authoritarian form in the 1930s and sought to legitimize their power through nationalist ideology after Piłsudski's death in 1935.
} 
far-right activists for the riots and for the death of Wacławski (Aleksiun, 2019; Graboń, 2008, pp. 167-186). The Main Academic Committee (Naczelny Komitet Akademicki), the largest representation of Polish academic youth, announced a day of mourning to be observed by Polish students of all higher education institutions (Kurcyusz, 1932, p. 60).

The main Warsaw ceremony in honor of Wacławski was held on 14 November. It began with the aforementioned religious service at the Academic Church of St. Anne, requested for 10 a.m. by the Academic Union of Fraternal Aid Societies (Centrala Akademicka Bratnich Pomocy, hereafter (ABP), an umbrella organization of Warsaw mutual aid societies of Polish youth. The rector of the church, Fr. Edward Szwejnic, ${ }^{8}$ who celebrated the mass, delivered a sermon in which he struck nationalist and messianic tones in the vein of Polish Romanticism: "The death of the late Wacławski has become the cement of the youth; this blood will cement all youth in Poland together and all the calculations of enemies will inevitably fail". The priest emphasized the idealism and vocation of young people to proclaim national and Christian values; he mentioned unidentified enemies lurking in the wings to threaten the unity and integrity of the national community, but at the same time he called for a calming of the emotions:

I warn you that provocateurs are working in Poland and they want to divide the academic youth, cause riots, so "be wise as serpents". God forbid! Do not put arguments in the hands of your enemies, do not let them get you down. I appeal to you in the name of the memory of this beautiful blood that has been shed, that you may remain as calm as possible. ("Przemówienie", 1931)

Although the academic chaplain was trying to temper the youth, he fueled the sense of insecurity among them.

The solemn mass, which is an established religious ritual itself, contained all the elements identified by Collins as necessary for a successful interaction ritual with long-term effects. The attention of the audience was focused on the figure of Wacławski, and Szwejnic's sermon intensified the mood of mourning and emphasized the significance of the recent events for the collective identity of students. In this way, it reinforced the construct of "Polish academic youth" as an imagined community based on ethnic categories (Anderson, 1997) and corresponded well with the agenda of the extreme right-wing groups. The mention of unidentified enemies - who could be easily identified as the Jewish community, blamed by the nationalist press for Wacławski's death, communists, commonly seen as provocateurs, or state and academic authorities seeking to discipline young people - gave ammunition to nationalist agitators.

Whatever numerical estimates we might assume, the church was certainly crowded, and the physical presence and emotional alignment of the bodies always favor the generation of

8 Edward Szwejnic (1887-1934), the first academic chaplain in Warsaw in the years 1932-1934; charismatic priest popular among young people; he initiated the publication of the religious and educational magazines luventus Christiana [Christian Youth] and Młodzież Katolicka [Catholic Youth], targeted at young Polish Catholics. 
group energy. Rhythmic entrainment was also facilitated by jointly uttered prayer formulas and ceremonial songs. Moreover, the Academic Church and the service naturally created barriers for strangers, both representatives of other religions and other ideological currents, uniting those gathered and separating them from the outside. All of these elements contributed to the intensification of the experience of community, which Durkheim called collective rapture. A successful ritual led to the development of a sense of belonging and group solidarity, even in those who found themselves there by accident or did not identify with nationalist ideology, such as many first-year students. It also generated the emotional energy of individuals, which in the ensuing situation was guided by the symbol of the social relationship, i.e. the figure of the deceased, and the political milieu he represented, i.e. the OWP and its ideals.

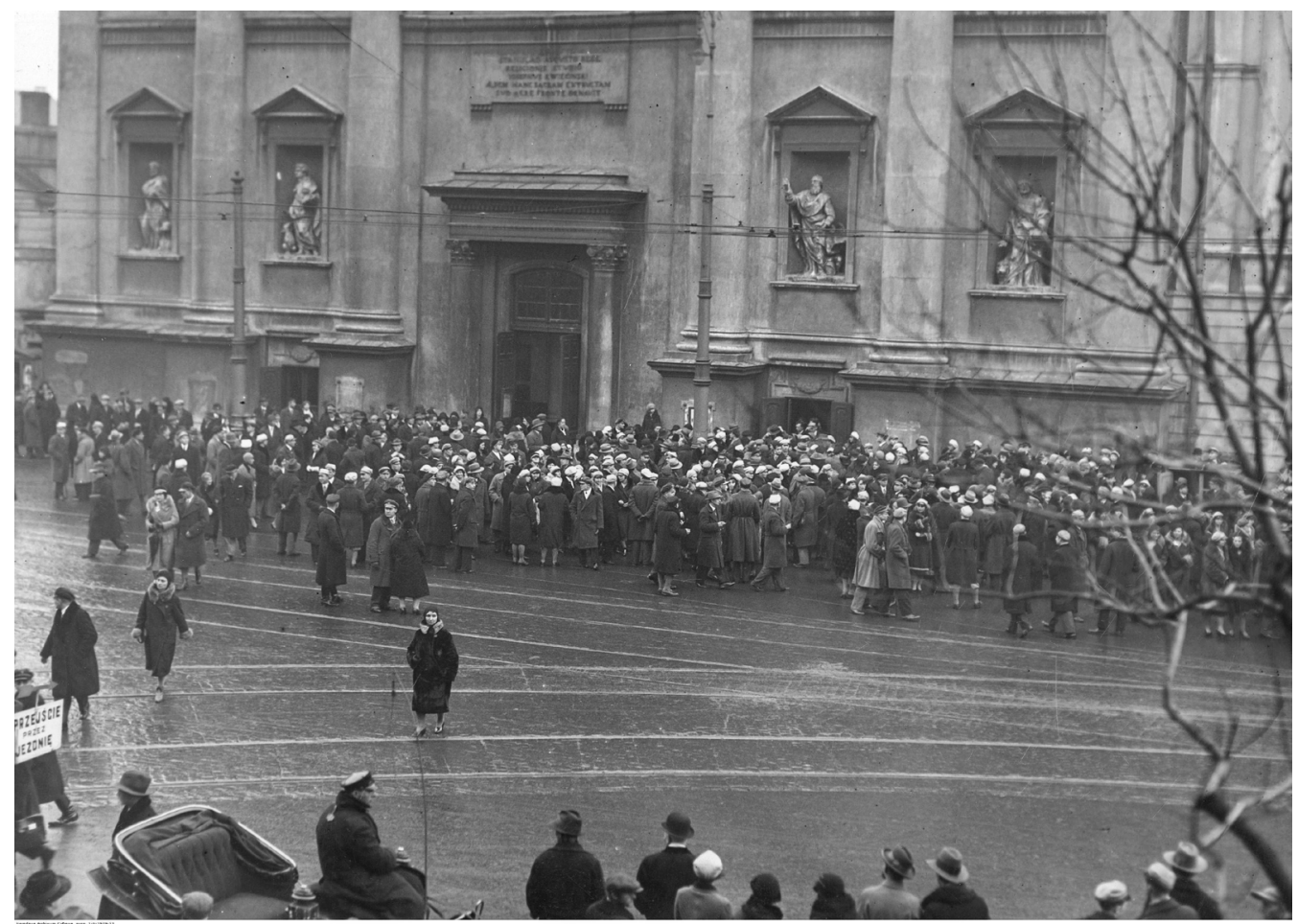

Students leaving the Academic Church of St. Anne after the requiem service for the soul of Stanisław Wacławski, 14 November 1931. Source: Narodowe Archiwum Cyfrowe, sygn. 1-N-3579-12.

After the requiem service, the far-right youth leaders called on participants to gather for a rally in the dormitory complex at Grójecka Street. The crowds of students escorted by the police walked along the main streets of the city to Narutowicz Square, where they began shouting: "Down with the Jews!", "Beat the Jews!", "We demand Catholic universities!", "We demand numerus clausus!", and sang patriotic songs ("Spokojny przebieg", 1931). The march through the city, singing and shouting sustained and strengthened the emotional energy generated during the mass. The rally was held in the courtyard of the dormitory complex with 
the participation of about 6,000 students ("Z uczelni wyższych", 1931). The OWP activists Zdzisław Węgliński, the head of CABP, and Jerzy Kurcyusz, the president of the university's Fraternal Aid Society, the main Polish mutual aid society at the university, gave speeches. The rally passed a resolution to join "the fight against the Jewish deluge in every area of public life" ("Liga Zielonej Wstążki", 1931), and to introduce an official numerus clausus for Jewish youth in institutions of higher education. Students demanded that Wacławski's murderers be brought to justice. The police, keeping in mind the recent riots at universities and collective violence in the city, applied various preventive measures, and, as the press reported, actually managed to maintain order ("Spokojny przebieg", 1931). Nevertheless, an effective interaction ritual took place and the far-right students created a group symbol.

Already during the November celebrations, political organizations started cultivating the symbol of Wactawski and managing the feelings that had been accumulated - as stressed by Collins, "[s]entiments can only be prolonged by symbols" (Collins, 2014, p. 37). The mourning rites were followed by a process of institutionalizing the cult: subsequent academic organizations, dominated by far-right youth, adopted anti-Jewish resolutions to honor the martyr (Natkowska, 1999, pp. 20-21). In January 1932, Wojciech Wasiutyński, then a fourth-year law student at Warsaw University, wrote in the Akademik Polski [Polish Academic], a press organ of the OWP Academic Branch, about the need to solve "the most important issue", i.e. the Jewish question, as follows:

We have enthusiasm, we have a program, we have the instincts of the masses behind us, we have the knowledge of the enemy and the ability to fight, we have faith in the sanctity of our goal, we have martyrs, what else do we need? (Wasiutyński, 1932)

Thus, he directly included Wacławski's death among elements of political struggle and tools to implement the anti-Jewish agenda.

In a bid to appeal to young people coming to Warsaw from the provinces and draw them to the chauvinist movement, what quickly came to the fore of far-right propaganda was Wacławski's social background. In January 1932, the Fraternal Aid Society at the university established a scholarship in the name of the Vilnius student, with the aim being "to help a fellow student who believes in and lives according to the principles in defense of which the late Stanisław Wacławski died", and which was intended for law students from peasant families (Kurcyusz, 1932, pp. 40-41). To support this fund, the Law Students' Society allocated 100 złotys, which made it possible to cover almost the entire tuition fees for the first year of studies in the 1931/32 academic year. ${ }^{9}$ Wacławski turned out to be a perfect symbol which could embody the modernization ambitions and nationalist views of the Polish peasantry, and associate them with the aspirations of the future elite, whom law students considered themselves to be.

9 In that year the tuition fee was 110 złotys; following a drastic increase in all academic fees introduced in July 1932, it was set at 270 złotys (Majewski, 2016, pp. 176-177). 
The far-right student milieu also used the figure of Wacławski to blackmail "ethnically Polish" students into a social boycott of Jewish students. At the end of 1931, a leaflet began to circulate at the Faculty of Medicine, presenting the position of the General Assembly of the Medical Students' Society. Launching a martyrological discourse, the young medics wrote as follows:

The death of our fellow student cannot be a sacrifice that will be in vain. We keep fighting and we will continue to fight the Jewry with all our ferocity [...].

Dear Fellows! It is forbidden to shake hands with those who bestially murdered our fellow student, the late Wacławski. Therefore, no Pole shall have relations with Jews. (Ulotka, 1931)

A resolution on economic and social boycott of Jews was also adopted by the Law Students' Society (11 December 1931) ("Z Koła Prawników", 1931). The OWP activists played a leading role in both organizations. From their perspective, membership in the imagined student community was to be based not so much on ethnic categories as on a moral code of chauvinistic radicalism.

Therefore, Wacławski was to become a touchstone of national belonging and the boundaries of the community. Not only Jews, but also those who opposed the far-right discourse and OWP ideology, could be excluded as enemies or suspects. The journalists who interpreted the Vilnius events differently than the right-wing press were condemned first ("Dwugłos", 1932). The Sanacja authorities, in turn, were accused of not defending the national interest and Polish academic youth, and of being subordinate to the Jews (Węgliński, 1933, pp. 30-31). This was accompanied by attacks on the left, which, according to this narrative, was betraying the ideas of nation in favor of class struggle ("W Walce", 1937).

Throughout the 1931/32 academic year, the right-wing academic press would mention Wacławski and regularly publish photographs from the funeral ceremonies in Vilnius and the requiem service in Warsaw. In this way, the far-right activists intended to sustain the emotional energy generated during the initial interaction. The poems published in the academic press are of particular importance, as they show the individual emotional involvement and internalization of the collective symbol, something that is difficult to capture for scholars. Simultaneously, this kind of material is also another example of how the student groups used the press to deepen identification with the chauvinist ideas through the symbol. In January 1932, the editors of Akademik Polski wrote that they had rejected an amateur piece which was "very good in content, but negligent in terms of form and rhyme" ("Odpowiedzi", 1932). On the front page of the same issue, however, a poem by Stanisław Pieńkowski was reprinted, entitled "Furia Addormentata", which had originally appeared in the right-wing weekly Myśl Narodowa [National Thought] at the beginning of December 1931, and unambiguously referred to the death of Wacławski (Pieńkowski, 1932).

The piece is composed in the form of a mother's lament over her son's body. The author employs the discourse of justice and vengeance that must be exercised in the face of loss. Although the pieta motif itself does not contain such connotations, in Pieńkowski's 
interpretation the mother of the slain victim wants revenge and calls for it: "Who will take vengeance for my son - who will be brave?". Moreover, Wacławski is presented both as a Christological figure and as a masculine exemplar of a Christian knight (Aleksiun, 2019, p. 358). He is portrayed as a defender of faith who, like Christ, died at the hands of the Jews: "My child! He followed the terrible cross of Christ, / An unclean force slaughtered him with stones". The image of the Jew as the personification of Evil was in fact deeply rooted in Polish folk culture, which endowed the Jews with demonic features, or even casted them as the Antichrist. ${ }^{10}$ As can be seen, then, the piece in question carries a strong emotional charge and makes references to Catholic and peasant mythology. On this basis the national movement could call for vengeance and defense of the Catholic faith. This perfectly matched the turn of the national camp towards Catholicism, which followed the publication of the book Kościół, naród i państwo [Church, Nation, and State] by the main ideologue of the Polish nationalist movement, Roman Dmowski (1927). Its message resonated particularly in the young generation (Kunicki, 2012, pp. 12-13). In the coming years, these motifs would be repeated in right-wing propaganda at anniversary celebrations.

The narrative of vengeance was reinforced by information about the course of the trial of the individuals charged with causing Wacławski's death. In April 1932, the two-year prison sentence passed on a Jewish student occasioned a comment expressing satisfaction that "the court [had] found [...] beyond doubt that the Jews were to blame for the street incidents and pointed to their racial hatred towards non-Jews" ("Proces wileński", 1932). ${ }^{11}$ On the other hand, when the original sentence was reduced by the appellate court to two months suspended sentence, the decision was reported in the right-wing student press without any editorial comment at all ("Zabójcy", 1932). Still, the very title of the news item, "Murderers of Wacławski before the Appellate Court", clearly indicated who was to blame, creating a sharp contrast with the sentence and provoking outrage. Furthermore, already in January 1932, a Warsaw student Stefan Rogala argued on the pages of Akademik Polski that Jews in Poland had impunity and did not bear any consequences for the crimes they committed. He also stated that Wacławski had been "cruelly murdered" (Rogala, 1932). This must have intensified the desire for retaliation and the pursuit of popular justice.

The effective perpetuation of the symbol of Wacławski and the meanings given to his death enabled far-right organizations to refer to them and invoke the interaction ritual in the following academic year, 1932/33. A visible sign of mobilization were the green ribbons, a symbol of the anti-Jewish boycott, worn by young OWP members between 9 and 11 November 1932 as well as "Chrobry swords", symbols of the movement, turned upwards as a sign of combat readiness (Natkowska, 1999, pp.33-34). On the eve of the first anniversary of Wacławski's death there was a riot at the law faculty, which

10 The image of the Jew in Polish folk culture has been extensively discussed by Alina Cała (Cała, 2012).

11 The prosecutor presented the November events as an attack by the Jews and self-defence on the part of the Christian population (Aleksiun, 2019, p. 352). 
was initiated by an OWP activist: at the beginning of a lecture he called on all first-year students to stand up and commemorate Wacławski. The negative reaction or confusion of some of them was perceived as a violation of and an insult to his sanctity and thus gave the activists an excuse to employ violence. A group of OWP militiamen broke into the lecture hall and started beating Jewish students and removing them from the room. Three students were seriously injured ("Nowe ekscesy", 1932). Ryszard Matuszewski, then a first-year law student, recalled that during his classes he was the only one not to respond to the call of the nationalists. As a result, he was beaten by OWP militiamen (Matuszewski, 1998, pp. 24-25). Wacławski's symbol was therefore used not only rhetorically, but also as a disciplinary tool. Following the incident, the Akademik Polski wrote about "provocative shouts" and presented the attack on Jews as an appropriate reaction ("Zajścia antyżydowskie", 1932). This only confirmed the continuance of interaction ritual chain, where anger and aggression are justified by the violation of group solidarity and its symbolic representation (Collins, 2014, pp. 64-65).

The process of shaping the symbol of Wacławski was completed with the anniversary mass, modeled on the first one. Held at the Church of St. Anne again, it was celebrated by Bishop Antoni Szlagowski, who enjoyed popularity and authority among the academic youth. His presence marked the special importance of the event. Delegations of student mutual aid organizations from all institutions of higher education in Warsaw displayed their banners during the ceremony, which was attended by about 2,000 people. Although it was far less than the year before ("Nowe ekscesy", 1932; "Rocznica", 1932), it was still about $10 \%$ of Warsaw students at the time. ${ }^{12}$ After the mass, OWP agitators called on those gathered to go to the dormitory complex at Grójecka Street for a student rally. The crowd of 1,500 people headed towards Narutowicz Square, and the interaction pattern from the previous year was recreated. The new element was a plaque in honor of Wactawski, funded by the CABP, placed in the dormitory complex (Węgliński, 1933, p. 30). In this way, the cult of the Vilnius student was to acquire a material medium of memory. After the ceremony, there were clashes between the OWP and communist and pro-government students. As reported in the press, the police intervention ended with the arrest of fifty students, including the president of Fraternal Aid, Zdzisław Węgliński ("Nowe ekscesy", 1932; "Zatrzymani", 1932). The events that followed further strengthened the interaction ritual that had been sustained for a year. The police removed the memorial plaque from the dormitory, which prompted the Fraternal Aid Society to adopt resolutions and take action to restore it, and reinforced the narrative of nationalist youth about the dishonesty and hostility of the ruling Sanacja regime (Węgliński, 1933, pp. 30-31). These events proved that a year after Wacławski's death it was possible to maintain emotions and connection between the student community and the far-right organizations as Wacławski's heirs.

12 In the 1932/33 academic year, Warsaw institutions of higher education had 19,487 students (Wittlinowa, 1937, p. 47). 


\section{Ritual Violence and Violence Ritual}

The interaction ritual solidified in 1932 was invoked by right-wing organizations around 10 November each year. These steps were also effective because the figure of Wactawski quickly became an element of far-right propaganda among high school students: as early as in September 1932 the international Jewish Telegraphic Agency reported on a boycott of bookstores in Świętokrzyska Street, where OWP academic activists persuaded, sometimes by force, their younger fellows not to buy textbooks from Jewish sellers in the name of the memory of Wacławski ("Opening of school", 1932). On entering university, some of them were already aware of this figure. They could acknowledge calls for remembrance during classes and solemn memorial masses as part of the academic culture to which they aspired as first-year students. Moreover, anniversary celebrations were organized by the officially recognized Fraternal Aid Society, which many freshmen joined as a matter of course, as it was the most important institution that provided financial support for students. Far-right groups, in turn, could use the ritual to draw younger cohorts into political life and to recruit them into their ranks.

The prelude to collective celebrations and violence were leaflets which appeared at institutions of higher education, calling for a proper commemoration of the hero by fighting Jews. Obituaries published in the press reproduced the far-right interpretation of the events of 1931, and at the same time maintained the atmosphere of mourning. These media provided an emotional stimulus, a spark to awake memory and restart the chain of interactions. For example, in 1933 the leaflets described Wacławski as "a soldier killed in the line of duty" and evoked the idealism and unity of the young generation: "On the anniversary of the death of our fellow student, we must firmly and unequivocally state our position. The young generation proved that they are ready to shed blood for ideals" ("Bezczelność", 1933). A year later, the message became even more radical, and the ONR, which grew out of Warsaw University student milieu, distributed a leaflet in which they did not shy away from openly calling for an anti-Jewish pogrom:

Jews ruling Poland openly and secretly - enemies of our Homeland - murdered a Pole, one of those who did not want to endure Jewish captivity.

The day of mourning for our murdered friend must be a day of retaliation.

Polish blood must fall on the Jews.

The innocently shed blood of Wacławski cries out for vengeance.

Poles!

Will you wait until you and your families are murdered by the Jews? Will you bear the shame of Jewish slavery any longer? [...] Will you not avenge the harm and tortures of the Poles imprisoned in Bereza Kartuska camp?

On the anniversary of Wacławski's death, Jewish blood must flow. Jewish houses and businesses, acquired through harm done to Poles and through their death, must burn on that day. (Odezwa antyżydowska, 1934) 
The discourse of revenge, which resurfaced here, was again enriched with traditional Christological metaphors accessible even to politically unaligned students: Wacławski's blood was to "fall on the Jews" like the blood of Christ, a clear reference to the scene of Jesus' condemnation by Pilate, which pointed to those guilty for the death of the Messiah (Mt 25:27). It was not the first time that Wacławski's death was clearly associated with a redemptive sacrifice. The line about the blood of a young man, a child of the Polish nation, also alluded to blood libel accusations. At the same time, the Jewish community was to suffer not only for the blame attributed to them, but also for the policies of the government. They played the role of a scapegoat, and this could channel the anger of ONR members and followers. Indeed, their organization was banned by the authorities in the summer of 1934, just a few months after it was formed, and many of the activists were incarcerated in Bereza Kartuska, a newly established detention facility for opponents of the regime, who were sent there without a court sentence, only on the basis of an administrative decision. For far-right activists, Bereza was a symbol of the hostility and oppressiveness of the Sanacja regime, which was again presented as favorable to Jews and treacherous to the "national cause".

The actual ritual started around the anniversary. The opening event was always a mass at the Academic Church with the participation of the university chaplain, the aforementioned Fr. Edward Szwejnic, and later Fr. Edward Detkens ${ }^{13}$ or Fr. Tadeusz Jachimowski. ${ }^{14}$ As in 1932, the banners of Fraternal Aid Societies from Warsaw and academic corporations would be displayed. Fr. Detkens was well known to some of the national youth leaders not only from his academic ministry, but also from the Jan Zamoyski Gymnasium in Warsaw, ${ }^{15}$ from which many members of far-right organizations had graduated. This means that on those days the former junior high school students would meet their teacher and spiritual guide. The mass, just like in 1931 or 1932, created a mood of solemnity, established the collective focus of attention, and generated strong emotions around the symbol of Wacławski; it also produced a sense of interpersonal solidarity as well as national and religious belonging. At the end, the students sang the "Youth Anthem", the anthem of the national-radical movement, sometimes followed by a traditional patriotic hymn "God Thou Hast Poland". The crowd leaving the church would always form a march and head for a rally. Face-to-face embodied presence, singing together and then moving in one direction was charging the batteries of the interaction ritual; as Collins writes: "Human bodies moving into the same place starts off the ritual process. There is a buzz, an excitement or at least wariness when human bodies are near each other" (Collins, 2014, p. 53). Marching together, then, created a sense of connection and commitment.

13 Edward Detkens (1888-1942), associate of Edward Szwejnic; rector of St. Anne's Academic Church from 1934, formerly associated with the Jan Zamoyski Gymnasium in Warsaw, educating young people in the spirit of ethnic nationalism; died in Dachau concentration camp, beatified in 1999 ("Błogosławiony Edward Detkens", 2014).

14 Tadeusz Jachimowski (1892-1944), vice-rector of St. Anne's Academic Church and academic chaplain from 1934; formerly chancellor of the Field Episcopal Curia in the rank of Colonel of the Polish Army, deprived of his position due to his anti-Piłsudski stance (Warsaw Rising Museum, n.d.).

15 I would like to thank Piotr Franz for drawing attention to this fact; he analyzed the ideological formation of the Jan Zamoyski Gymnasium in the interwar period in his PhD thesis (Franz, 2020). 
The next link in the ritual chain was the student gathering, which took place in the courtyard of Warsaw University, in Politechnika Square or in the hall of the Hygiene Society at Karowa Street, between the university campus and the seat of the government. Presidents of Fraternal Aid Societies and far-right organizations would give speeches in which they read Wactawski's death in the context of current political struggles. The previously generated emotional energy and sense of belonging gained political meaning, a collective conviction of moral righteousness was created, and a readiness to defend the group and its symbols against threats was born (Collins, 2014, pp.47-48). The texts of these speeches have not been preserved, but their main idea can be gleaned from a speech given by Witold Borowski, a Warsaw University student and the president of All-Polish Youth in Warsaw, delivered during the celebrations in Lviv in 1936:

By dying we become more numerous [...]. The ideas of the national movement, which prove the claim that blood shed for a good cause is not wasted but becomes the leaven of new life, spread more and more. And there is no corner of Poland today that they would not reach. ("Ginąc, stajemy się liczniejsi...", 1936)

He further referred to "the attitude of the peasants-nationalists of Odrzywół and Przytyk", ${ }^{16}$ whose sacrifice would lead to victory and the emergence of Great Poland ("Ginąc, stajemy się liczniejsi", 1936). In this way, Borowski created an imaginary community of new Poles, fighting for chauvinistic ideals. His speech employed both the nationalist mysticism of death and the motif of national awakening initiated by "the martyrdom of Wacławski".

These speeches sowed the seeds of righteous anger and desire to ritually punish those who had violated the values of such a community. From there it was only a step to the outbreak of aggression, which, in the eyes of the mobilized group, was supposed to restore social order (Tokarska-Bakir, 2019). In 1935, just after the speeches, the outraged crowd of students vandalized the rector's building at Warsaw University, invaded lecture halls and attacked Jewish students. Then the students rushed to the main building of Warsaw Polytechnic, smashing windows of Jewish stores along the way and assaulting passers-by. When they got there they clashed with communist activists and Jewish students ("Awantury", 1935). In another scenario, typical of the years 1937-1938, the university rally itself was peaceful, but the crowd of students transformed into a group that initiated riots in Krakowskie Przedmieście and in the city center. In 1937, in Nowy Świat and in Trzech Krzyży Square, students broke shop windows and clashed with the police ("Wczorajsze demonstracje", 1937). A year later, fights with the police dominated this phase of the ritual: security forces blocked the march from proceeding to the center, and then broke up street brawls in various parts of the city ("Manifestacje", 1938).

16 In Odrzywół, between 20 and 29 November 1935, attempts by the Youth Section of the National Party and their peasant sympathisers to provoke a pogrom resulted in clashes with the police, during which thirteen local people were killed. In Przytyk, on 9 March 1936, the most famous pogrom took place, as a result of which three people were killed and about sixty were injured, and many Jewish houses and stores were destroyed. The events in Przytyk became a spur for the far-right movement to unleash an antisemitic campaign (Gapys \& Markowski, 1999; Kijek, 2019; Penkalla, 1990; Rothenberg, 1986). 
The course of events largely depended on the attitude of academic authorities and on the strategy and preventive measures adopted by the police. In 1933, following violent clashes between nationalist and pro-government youth in October, the University of Warsaw was closed, and Warsaw Polytechnic and the Warsaw School of Economics became a theater of violence around the anniversary (Lachowicz, 1933; "Zamknięcie Uniwersytetu", 1933). A year later, the police dispersed the crowd leaving St. Anne's Church, thus preventing not only a march but also a rally. In 1935, Warsaw University authorities allowed a rally in the university courtyard, but they tried to prevent students of other institutions from participation. This ultimately resulted in riots on the campus when the student crowd forced the gate. This experience probably prompted the rectors to close their institutions and suspend classes around 10 November in the following years ("Z uczelni wyższych", 1937). From 1937, then, far-right organizations were unable to assemble at the university, and they held their rallies in the building of the Hygiene Society at Karowa Street, a popular venue for lectures and conferences. Although this meant that Jewish students were not exposed to aggression, and university buildings - to damage, this did not put the brakes on students in the urban space. And what is more, the entire impetus of aggression was then directed against Jewish inhabitants and shopkeepers, which meant that their health and life was at risk and they were bound to suffer property damage. Violence was not a deviation from the norm, but turned into part of the annual ritual and co-created emotional interaction between the participants.

Bearing in mind the described events and their press coverage, it becomes clear that in the first years after Wacławski's death far-right organizations focused on institutionalizing a quasi-religious cult of him as a martyr. They almost immediately aimed at universalizing the symbol and expanding it beyond the academic context as well. Warsaw students involved in the activity of local branches of far-right parties requested masses for Wacławski's soul and inspired antisemitic acts of violence in the provinces (Kijek, 2018; "Zajścia antyżydowskie", 1931). After 1935, along with the increasing wave of antisemitic protests throughout the country, the far-right press and academic magazines placed the figure of Wacławski at the heart of the mythology of "those who fell on the frontline of the fight against Jews". On the "roll of honor of the fallen", next to Wacławski appeared, among others, the student Jan Grotkowski, who died in a fight with Jewish hooligans in 1932, and the peasants from Odrzywót (cf. note 15 above) ("Niech kraj mój życie weźmie", 1936). The pantheon of martyrs for Great Poland included representatives of all social strata, and thus presented national unity and solidarity (Kostrzewa, 1936). It also referred directly to the martyrdom of the early Christians and corresponded with the lives of saints popular in Catholic teaching. As Joanna Tokarska-Bakir shows, Żywoty świętych [The Lives of the Saints] by Piotr Skarga (1536-1612, a renowned Polish Jesuit author), rich in descriptions of cruel Roman persecutions and containing the names of innocents murdered by Jews, was one of the most popular Polish books in the interwar period, often the first religious textbook that played an important role in perpetuating traditional anti-Judaic stereotypes (Tokarska-Bakir, 2018, p. 118). The story of Wacławski's "martyrdom" fitted in well with the ideas and sensitivities of Catholic youth thus formed. 


\section{Conclusions}

By the end of the 1930s the cult of Wactawski had already been firmly embedded in the imagination of the far-right movement and the broader student community. Therefore, when in 1938 the press published an appeal from Wacławski's family to refrain from violent celebrations and to commemorate "their son and brother" with hard work instead, it did not meet with a positive response from academic youth. The right-wing press raised serious doubts about the authenticity of the letter, ${ }^{17}$ but the main reason for its rejection was the fact that the anniversary of Wactawski's death and the successful ritual were the keystone of the academic nationalist community and an important tool for far-right mobilization.

The symbol of Wactawski and the interaction ritual created around it had an identity-forming significance. The death of the Vilnius student caused the accumulation of a great deal of negative emotions but the celebrations and performances organized around it intensified this emotional energy. Each year, the November anniversary became a moment of focused awareness and a peak of shared emotions for participants of the interaction. Personal experience of memorial masses and collective violence crystalized in personal symbols and determined the participants' self-identification in opposition to Others, i.e. Jews (as anti-Christian), communists (as political enemies and provocateurs), and the Sanacja regime (as hostile to the "national cause" and allied with Jews).

These celebrations had the power to shape students' attitudes in the short and in the long term. Firstly, intense interaction rituals shaped not only situational behavior, but also the judgements and declarations that the participants of the ritual expressed while it was performed. However, this did not necessarily continue in other interactions in which the emotional pressure was lower. This is clearly seen in the case of freshmen or students who were not directly associated with political organizations. Secondly, such intense moments of collective emotions, as Collins states, can function as deeper formative experiences. They sublimate into personal experiences, and the most vivid symbols become internalized and translate into permanent beliefs and norms of behavior (Collins, 2014, p. 43). Ritual participation could also have significant biographical consequences, as in the case of Jan Barański, who became a leader of the far-right in Częstochowa and an important activist of the Academic Section of the National Party (SA SN) in Warsaw. While still a junior high school student, he took part in the organization of celebrations in honor of Wacławski, for which he was repressed by state authorities for the first time and

17 Previous studies unreservedly accept the authenticity of the letter from Wacławski's family (Natkowska, 1999, pp. 166-167; Rudnicki, 1985, p. 118; Srebrakowski, 2004, p. 575), but there are some doubts about it. Although the appeal was addressed to far-right youth, it was published only in the government press and left-wing magazines. For this reason, it was discredited by the right-wing press. Moreover, at the end of November 1938, the Vilnius daily Stowo [Word] published a reportage on a meeting with Wacławski's family in Sieniawa. The latter was not only to denounce the letter, but also to address words of appreciation to the chauvinistic students for their veneration of the memory of the deceased ("Stanisław Wacławski pozostanie zawsze symbolem"; Szychowski, 1938). 
expelled from school. It was a moment of political initiation which strengthened his ongoing socialization into the nationalist movement (Barański, 1984, pp.42-45).

Different practices and discourses of Polish radical nationalism among the youth of the 1930s converged in the figure of Wactawski. It was incorporated not only into a system of antisemitic and anti-Judaic stereotypes and images, but also into the network of Catholic references and rhetoric. They were appealing particularly to the generation growing up in the shadow of the crisis of European culture after the experiences of the First World War and the Bolshevik Revolution, a generation who considered themselves restorers of the Polish and Catholic spirit. Paradoxically, the symbol of Wacławski also had enormous inclusive potential as a narrative of an ambitious peasant child who sacrificed his life for his convictions. This inclusion was, of course, ethnically limited, and a community built around the symbol was otherwise exclusive. In this way, the interactive ritual strengthened both the existing national divisions and the structures of symbolic violence. It sanctioned the political and cultural hegemony of Polish students in the university space by excluding Jewish students, regardless of their social background.

Usually, members of the imagined community are emotionally attuned to each other. They co-perceive and co-feel, thanks to which on the one hand they themselves experience a sense of security and belonging, and on the other hand they can imperceptibly reproduce the common world of everyday life and its structures. Hence, the study of symbols and the emotional energy they stimulate is important not only for understanding mobilizations for violence and processes of radicalization, but also for the functioning of any community or social movement.

\section{References}

\section{Primary sources}

Awantury na Uniwersytecie i na Politechnice. (1935, November 10). Gazeta Polska, 16. Barański, J. (1984). Lata młodości i walki. Veritas.

Bezczelność i prowokacja. (1933, November 11). Gazeta Polska, 4.

Dwugłos. (1932, January 1). Akademik Polski, 1932(1), 2.

E. L. [Lewin, E.]. (1935). Nasz Listopad Akademicki. Trybuna Akademicka, 1935(10), 3.

Echa hec antyżydowskich w stolicy: Rezultaty akcji "Gazety Warszawskiej". (1932, November 11). Gazeta Polska, 3.

Ginąc, stajemy się liczniejsi... Hołd młodzieży akademickiej Lwowa poległym za Wielką Polskę. (1936, November 15). Tygodnik Polityczny Warszawskiego Dziennika Narodowego, 1936(45), 2. Kostrzewa, J. (1936, November 8). Apel poległych. Falanga, 1936(20), 1.

Krwawe zajścia w Wilnie: Śmierć studenta Wacławskiego - 43 rannych. (1931, November 11). ABC, 1.

Kurcyusz, J. (1932). Sprawozdanie Towarzystwa "Bratnia Pomoc" SUW za rok 1931/1932. Towarzystwo Bratnia Pomoc SUW. 
Lachowicz, A. (1933, December 4). Rocznica śmierci śp. Stanisława Wacławskiego. Akademik Polski, 1933(6), 3.

Lachowicz, A. (1939). Rocznica śmierci śp. Stanisława Wacławskiego. Akademik Polski, 1939(6), 3. Liga Zielonej Wstążki. (1931, December). Akademik Polski, 1931(12), 2.

Manifestacje w rocznicę śmierci śp. St. Wacławskiego. (1938, November 10). Warszawski Dziennik Narodowy, 8.

Matuszewski, R. (1998). Chmury na pogodnym niebie. Vipart.

Niech kraj mój życie weźmie... Zgasłym za Wielką Polskę. (1936, November 8). Tygodnik Polityczny Warszawskiego Dziennika Narodowego, 1936(44), 1.

Niwel [Lewin, E.]. (1933, January). Nasze sezony. Trybuna Akademicka, 1933(1), 1-2.

Nowe ekscesy bojówek OWP w stolicy. (1932, November 11). Gazeta Polska, 12.

Odezwa antyżydowska Obozu Narodowo Radykalnego w zwiq̨zku z rocznica śmierci Stanisława Wacławskiego. (1934). Archiwum Akt Nowych, Zbiór druków ulotnych, 192, p. 1.

Odpowiedzi Redakcji. (1932, January 1). Akademik Polski, 1932(1), 7.

Opening of school in Warsaw marked by clashes after anti-Jewish boycott agitation. (1932, September 9). Jewish Daily Bulletin, 1.

Pieńkowski, S. (1932, January 1). Furia Addormentata. Akademik Polski, 1932(1), 1.

Proces wileński. (1932, April 24). Akademik Polski, 1932(6), 1.

Przemówienie ks. B. Szwejnica, rektora, kościoła akademickiego w Warszawie, na nabożeństwie żałobnem za duszę św. pamięci Stanisława Wacławskiego. (1931, December). Akademik Polski, 1931(12), 1.

Rocznica śmierci śp. Wacławskiego. (1932, November 21). Akademik Polski, 1932(13), 1. Rogala, S. (1932, January 1). Tylko fakty. Akademik Polski, 1932(1), 2.

Spokojny przebieg wczorajszych demonstracyj akademickich. (1931, November 15). Gazeta Polska, 10.

Szychowski, K. (1938, December 13). Stanisław Wacławski pozostanie zawsze symbolem walki o Wielką Polskę. List rodziny był sfałszowany. Falanga, 1938(54), 7.

Szychowski, K. (1938, November 29). Śp. Stanisław Wacławski i jego rodzina. Słowo, 3. [Ulotka]. (1931). Biblioteka Uniwersytecka w Warszawie, Gabinet Dokumentów Życia Społecznego, DU XVII P28[3085].

W dniu 10-go listopada 1935 roku mija czwarta rocznica tragicznej śmierci ś. p. kolegi Stanisława Wacławskiego [Obituary]. (1935). National Digital Library POLONA. https://polona.pl /item/do-ogolu-polskiej-mlodziezy-akademickiej-uniwersytetu-stefana-batorego-incipit -w-dniu,MTIwNzQ1ODI4/0/\#info

W dniu 10 listopada 1937 r. mija 6 lat od chwili, gdy pod kamieniem żydowskiej bojówki padł student Wszechnicy Batorowej, członek Młodzieży Wszechpolskiej ś. p. Stanisław Wacławsk i [Afisz]. (1937). National Digital Library POLONA. https://polona.pl/item/akademicy-incipitw-dniu-10-listopada-1937-mija-6-lat-od-chwili-gdy-pod-kamieniem,MTIzMjExMjcy/0/\#info W Walce o Wielką Polskę. (1937, November 10). Alma Mater [Special edition].

Wasiutyński, W. (1932, January 1). Z najważniejszych zagadnień. Akademik Polski, 1932(1), 3. 
Wczorajsze demonstracje studentów. (1937, November 11). Gazeta Polska, 11.

Węgliński, Z. (1933). Sprawozdanie z działalności Towarzystwa Bratnia Pomoc SUW 1932/1933. Towarzystwo Bratnia Pomoc SUW.

Wittlinowa, H. (1937). Atlas szkolnictwa wyższego. Ministerstwo Wyznań Religijnych i Oświecenia Publicznego.

Zabójcy śp. Wacławskiego przed sądem apelacyjnym. (1932, September 7). Akademik Polski, 1932(8), 4.

Zajścia antyżydowskie. (1931). Sprawy Narodowościowe, 1931(6), 644-654.

Zajścia antyżydowskie na l-ym roku prawa. (1932, November 21). Akademik Polski, 1932(3), 3.

Zamknięcie Uniwersytetu Warszawskiego. (1933, October 27). Gazeta Polska, 1-2.

Zatrzymani studenci pozostają w areszcie. (1932, November 12). Gazeta Polska, 4.

Z Koła Prawników SUW. Walne Zebranie. (1931, December). Prawo, 1931(10), 652.

Z uczelni wyższych. (1931, November 14). Kurier Warszawski, 13.

Z uczelni wyższych. (1937, November 10). Kurier Warszawski, 4.

\section{Secondary sources}

Aleksiun, N. (2011). Christian corpses for Christians! Dissecting the anti-Semitism behind the Cadaver Affair of the Second Polish Republic. East European Politics and Societies, 25(3), 393-409. https://doi.org/10.1177/0888325411398913

Aleksiun, N. (2012). Jewish students and Christian corpses in interwar Poland: Playing with the language of blood libel. Jewish History, 26(3-4), 327-342. https://doi.org/10.1007/s10835 -012-9163-5

Aleksiun, N. (2019). Studenci z pałkami: Rozruchy antyżydowskie na Uniwersytecie Stefana Batorego w Wilnie. In K. Kijek, A. Markowski, \& K. Zieliński (Eds.), Pogromy Żydów na ziemiach polskich w XIX i XX wieku (Vol. 2, pp. 327-369). Instytut Historii PAN.

Anderson, B. (1997). Wspólnoty wyobrażone: Rozważania o źródłach i rozprzestrzenianiu się nacjonalizmu (S. Amsterdamski, Trans.). Znak.

Błogosławiony Edward Detkens - prezbiter i męczennik. (2014). In Czytelnia: Święci i błogosławieni. Internetowa Liturgia Godzin. Retrieved January 21, 2021, from https://www.brewiarz .katolik.pl/czytelnia/swieci/08-10d.php3

Bukowska-Marczak, E. (2019). Przyjaciele, koledzy, wrogowie? Relacje pomiędzy polskimi, żydowskimi i ukraińskimi studentami Uniwersytetu Jana Kazimierza we Lwowie w okresie międzywojennym (1918-1939). Wydawnictwo Neriton.

Cała, A. (2012). Żyd - wróg odwieczny? Antysemityzm w Polsce i jego źródła. Nisza.

Collins, R. (2014). Interaction ritual chains. Princeton University Press.

Franz, P. (2020). Erziehung der Nation: Rechte Bildungsnetzwerke und ihr national-radikales Erbe in Warschau, 1905-1939 [Unpublished doctoral dissertation]. Europa-Universität Viadrina.

Gapys, J., \& Markowski, M. B. (1999). Zajścia antyżydowskie w Odrzywole w 1935 r. wyrazem wpływów endecji w województwie kieleckim. Biuletyn Kwartalny Radomskiego Towarzystwa Naukowego, 34(1), 43-58. 
Garlicki, A. (2008). Piękne lata trzydzieste. Prószyński i S-ka.

Graboń, A. (2008). Problematyka żydowska na łamach prasy akademickiej w okresie międzywojennym. Wydawnictwo MCDN.

Kijek, K. (2018). Zanim stał się Przytyk: Ruch narodowy a geneza zajść antyżydowskich w województwie kieleckim w latach 1931-1935. Zagłada Żydów. Studia i Materiały, 14, 45-79. https://doi.org/10.32927/ZZSiM.60

Kijek, K. (2019). Pogrom, którego nie było, tragedia, która przyszła w zamian: Zajścia w Odrzywole, 20-29 listopada 1935 r. In K. Kijek, A. Markowski, \& K. Zieliński (Eds.), Pogromy Żydów na ziemiach polskich w XIX i XX wieku (Vol. 2, pp. 391-408). Instytut Historii PAN.

Kunicki, M. S. (2012). Between the brown and the red: Nationalism, Catholicism, and communism in twentieth-century Poland. Ohio University Press. https://doi.org/10.1353/book.19160 Lipski, J. J. (2016). Idea Katolickiego Państwa Narodu Polskiego: Zarys ideologii ONR "Falanga". Wydawnictwo Krytyki Politycznej.

Majewski, P. M. (2016). Społeczność akademicka 1915-1939. In P. M. Majewski (Ed.), Dzieje Uniwersytetu Warszawskiego 1915-1945 (pp. 51-323). Wydawnictwa Uniwersytetu Warszawskiego. https://doi.org/10.31338/uw.9788323522973.pp.51-324

Michlic, J. B. (2006). Poland's threatening other: The image of the Jew from 1880 to the present. University of Nebraska Press. https://doi.org/10.2307/j.ctt1djmhhh

Natkowska, M. (1999). Numerus clausus, getto ławkowe, numerus nullus, "paragraf aryjski": Antysemityzm na Uniwersytecie Warszawskim 1931-1939. Żydowski Instytut Historyczny.

Nijakowski, L. M. (2013). Rozkosz zemsty: Socjologia historyczna mobilizacji ludobójczej. Wydawnictwo Naukowe Scholar.

Penkalla, A. (1990). The 'Przytyk incidents' of 9 March 1936 from archival documents. Polin: Studies in Polish Jewry, 5, 327-359. https://doi.org/10.2307/j.ctv1rmh3j.23

Rossoliński-Liebe, G., \& Starek, J. (2016). Alma mater antisemitica: Akademisches Milieu, Juden und Antisemitismus an den Universitäten Europas zwischen 1918 und 1939. new academic press.

Rothenberg, J. (1986). The Przytyk pogrom. Soviet Jewish Affairs, 16(2), 29-46. https://doi.org /10.1080/13501678608577536

Rudnicki, S. (1985). Obóz Narodowo Radykalny: Geneza i działalność. Czytelnik.

Rudnicki, S. (2018). Falanga: Ruch Narodowo-Radykalny. Oficyna Wydawnicza ASPRA-JR.

Srebrakowski, A. (2004). Sprawa Wacławskiego: Przyczynek do historii relacji polsko-żydowskich na Uniwersytecie Stefana Batorego w Wilnie. Przeglad Wschodni, 9(3), 575-601.

Tokarska-Bakir, J. (2018). Pod klątwa: Społeczny portret pogromu kieleckiego (Vol. 1). Wydawnictwo Czarna Owca.

Tokarska-Bakir, J. (2019). Pogrom jako akt kontroli społecznej: Springfield 1908 - Polska 1945-1946. In A. Grabski (Ed.), Pogromy Żydów na ziemiach polskich w XIX i XX wieku (Vol. 4, pp. 467-487). Instytut Historii PAN.

Warsaw Rising Museum. (n.d.). Tadeusz Jachimowski. In Powstańcze biogramy. Retrieved February 13, 2020, from https://www.1944.pl/powstancze-biogramy/tadeusz-jachimowski ,12348.html 
Zackiewicz, G. (2011). Wydarzenia wileńskie z listopada 1931 roku w komentarzach ówczesnej prasy polskiej. Biuletyn Historii Pogranicza, 11, 41-56.

Żyndul, J. (1994). Zajścia antyżydowskie w Polsce w latach 1935-1937. Fundacja im. Kazimierza Kelles-Krauza; Agencja Scholar.

\title{
Kult męczennika. Symbol Stanisława Wacławskiego i rytuały przemocy w warszawskim środowisku studenckim lat trzydziestych XX wieku
}

\begin{abstract}
Abstrakt
W habitusie międzywojennych radykałów przemoc grała kluczową rolę i była szczególnie afirmowana w ruchach skrajnie prawicowych, które znajdowały podatny grunt dla swoich idei w środowiskach studenckich. Jednak wpływ systemów idei głoszonych przez ideologów na masy studenckie wydaje się ograniczony i pośredni. Poparcia studentów dla antysemityzmu i ekstremizmu nie można tłumaczyć jedynie uwarunkowaniami kulturowymi, ideologią czy inżynierią polityczną. Potrzebne są tu etapy pośrednie, łączące radykalną ideologię z działaniami aktorów społecznych. W niniejszym tekście dowodzę, że funkcję taką pełnił w środowisku akademickim symbol w postaci Stanisława Wacławskiego, studenta i członka Obozu Wielkiej Polski, który zginął podczas antysemickich zamieszek w Wilnie w 1931 roku. Jego postać stanowiła kluczowy element antysemickiego dyskursu prasy skrajnej prawicy i była wykorzystywana przez stowarzyszenia akademickie do konstruowania corocznego rytuału przemocy w latach 30. Aby pokazać, że czynnikami, które wyjaśniają, w jaki sposób zwykli studenci byli mobilizowani do zbiorowej przemocy i pozyskiwani dla szowinistycznego programu, były również emocje i osobiste relacje, a nie tylko identyfikacja polityczna i agitacja, stosuję podejście mikrosocjologiczne i czerpię z teorii „łańcuchów rytuałów interakcji” Randalla Collinsa.
\end{abstract}

Słowa kluczowe: skrajna prawica; przemoc zbiorowa; antysemityzm; łańcuchy rytuałów interakcyjnych; Stanisław Wacławski; studenci; Polska międzywojenna

\section{Citation}

Mrzygłód, I. (2021). The cult of the martyr: The symbol of Stanisław Wacławski and rituals of violence in the Warsaw student milieu of the 1930s. Sprawy Narodowościowe: Seria nowa, 2021(53), Article 2545. https://doi.org/10.11649/sn.2545 